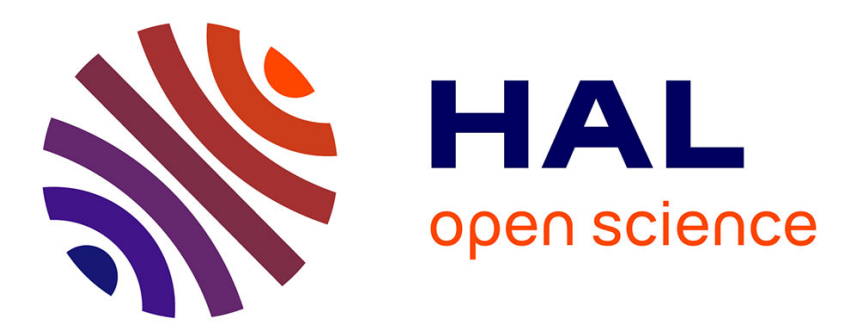

\title{
Serpentinization of oceanic peridotites: 2. Kinetics and processes of San Carlos olivine hydrothermal alteration
}

Benjamin Malvoisin, Fabrice Brunet, Julie Carlut, Stéphane Rouméjon, Mathilde Cannat

\section{- To cite this version:}

Benjamin Malvoisin, Fabrice Brunet, Julie Carlut, Stéphane Rouméjon, Mathilde Cannat. Serpentinization of oceanic peridotites: 2. Kinetics and processes of San Carlos olivine hydrothermal alteration. Journal of Geophysical Research: Solid Earth, 2012, 117 (B04102), 10.1029/2011JB008842 . insu-01571061

\section{HAL Id: insu-01571061 https://hal-insu.archives-ouvertes.fr/insu-01571061}

Submitted on 1 Aug 2017

HAL is a multi-disciplinary open access archive for the deposit and dissemination of scientific research documents, whether they are published or not. The documents may come from teaching and research institutions in France or abroad, or from public or private research centers.
L'archive ouverte pluridisciplinaire HAL, est destinée au dépôt et à la diffusion de documents scientifiques de niveau recherche, publiés ou non, émanant des établissements d'enseignement et de recherche français ou étrangers, des laboratoires publics ou privés. 


\title{
Serpentinization of oceanic peridotites: 2. Kinetics and processes of San Carlos olivine hydrothermal alteration
}

\author{
Benjamin Malvoisin, ${ }^{1,2}$ Fabrice Brunet, ${ }^{1,2}$ Julie Carlut, ${ }^{1,3}$ Stéphane Rouméjon, ${ }^{3}$ \\ and Mathilde Cannat ${ }^{3}$
}

Received 2 September 2011; revised 13 January 2012; accepted 18 January 2012; published 4 April 2012.

[1] The kinetics of the reaction $(\mathrm{Mg}, \mathrm{Fe})$-olivine $+\mathrm{H}_{2} \mathrm{O} \rightarrow$ serpentine + magnetite + brucite $+\mathrm{H}_{2}$ were investigated at 500 bars in the $250-350^{\circ} \mathrm{C}$ range using natural olivine (San Carlos; $\mathrm{Fo}_{91}$ ) with grain sizes between 1 and $150 \mu \mathrm{m}$ and for run durations up to $514 \mathrm{~d}$. The amount of magnetite produced, which directly relates to reaction progress, was accurately monitored using up to 24 time-resolved magnetic measurements per experiment. Eighty percent of serpentinization was achieved after $60 \mathrm{~d}$ for olivine grain sizes of 5-15 $\mu \mathrm{m}$ and after $500 \mathrm{~d}$ for grain sizes of $50-63 \mu \mathrm{m}$. Serpentinization kinetics were found to be inversely proportional to the geometrical surface area of the starting olivine grains. They were one or two orders of magnitude slower than serpentinization kinetics commonly used for modeling serpentinization-related processes. The nature of the serpentine mineral product depended on the initial olivine grain size (IGS); for IGS in the 5-150 $\mu \mathrm{m}$ range lizardite formed, and olivine dissolution was the rate-limiting process. At IGS below $5 \mu \mathrm{m}$, chrysotile crystallized instead of lizardite, and the relationship between olivine surface area and reaction kinetics no longer held. We infer that for such small olivine grain sizes dissolution is no longer the rate-limiting process. Serpentinization in our experiments was associated with the creation of new reactive surface area according to two cooperative processes: etch pits formation associated with dissolution and grain fracturing for IGS above $20 \mu \mathrm{m}$. Interestingly, fractures and etch pits with similar geometry and sizes were also observed for residual olivine (with a typical grain size of $50 \mu \mathrm{m}$ ) in serpentinized peridotite samples from the Southwest Indian Ridge. This suggests that the processes governing olivine serpentinization kinetics in our experiments are similar to those prevailing in natural systems. We therefore suggest that the new kinetic data set that we present here, which encompasses a range of olivine grain sizes and reaction temperatures, is relevant to the serpentinization of olivine in the oceanic crust insofar as water is available.

Citation: Malvoisin, B., F. Brunet, J. Carlut, S. Rouméjon, and M. Cannat (2012), Serpentinization of oceanic peridotites: 2. Kinetics and processes of San Carlos olivine hydrothermal alteration, J. Geophys. Res., 117, B04102, doi:10.1029/2011JB008842.

\section{Introduction}

[2] Serpentinization reactions have been recognized to play a major role in modifying the physical properties of the oceanic lithosphere [i.e., Fyfe, 1974; Dyment and Arkani-Hamed, 1995; Escartín et al., 1997; Oufi et al., 2002]. These reactions have been extensively characterized at the thin section scale: for example, mineralogical

\footnotetext{
${ }^{1}$ Laboratoire de Géologie, Ecole Normale Supérieure, CNRS, Paris, France.

${ }^{2}$ Maison des Géosciences, Institut des Sciences de la Terre, Université de Grenoble 1, CNRS, Grenoble, France.

${ }^{3}$ Laboratoire de Géosciences Marines, Institut de Physique du Globe de Paris, CNRS, Paris, France.

Copyright 2012 by the American Geophysical Union. 0148-0227/12/2011JB008842
}

identification of the serpentine polymorphs [Andreani et al., 2004], geometry of the alteration texture or mesh texture [e.g., Wicks and Whittaker, 1977], distribution of the magnetic minerals [Oufi et al., 2002], reaction paths [Bach et al., 2006; Beard et al., 2009], and crystallographic relationships between reactants and serpentine products [Rumori et al., 2004; Boudier et al., 2010]. The transposition of mineralogical serpentinization data to geophysical processes at the regional scale, for example, heat generation or fluid flow, has been addressed with numerical modeling [Allen and Seyfried, 2004; Delescluse and Chamot-Rooke, 2008; Emmanuel and Berkowitz, 2006; Iyer et al., 2010]. However, these models must directly or indirectly deal with the complex interplay between reaction, deformation and water transport in the rock medium. The rate of serpentinization reaction is indeed controlled (1) by the water supply 
[MacDonald and Fyfe, 1985] which can itself be enhanced by fracturing promoted by the volume change associated with the reaction [Fletcher et al., 2006; Røyne et al., 2008; Rudge et al., 2010] and (2) by the kinetics of the reaction when water has permeated the rock. A general rate law for the kinetics of oceanic peridotite serpentinization is consequently a critical input parameter to any of such model. The rate of synthetic forsterite hydration determined experimentally by Martin and Fyfe [1970] has become over the years the reference data set to parameterize serpentinization kinetics in geophysical models. These authors showed that, between 200 and $325^{\circ} \mathrm{C}$, more than 40 molar \% olivine is transformed into hydrous products (chrysotile and brucite) within $200 \mathrm{~h}$. Their experimental conversion rates for synthetic forsterite (initial grain size (IGS) of 58-79 $\mu \mathrm{m}$ ) when plotted as a function of temperature, display a bell-shaped curve with a maximum centered around $260^{\circ} \mathrm{C}$. Comparable conversion rates were found by Wegner and Ernst [1983] for synthetic forsterite $(40$ molar \% of olivine transformed at $270^{\circ} \mathrm{C}$ and $1 \mathrm{kbar}$ after $700 \mathrm{~h}$, with IGS comprised between 62 and $74 \mu \mathrm{m}$ ). On the other hand, similar experiments (temperature and grain size) performed with natural olivine $\left(\mathrm{Fo}_{85}\right)$ by Martin and Fyfe [1970] (IGS $=58-79 \mu \mathrm{m} ; T=$ $250^{\circ} \mathrm{C}$ ), as well as experimental studies dedicated to other purposes than kinetic investigation (Moody [1976] with IGS $=20-100 \mathrm{~mm}$ and $T=300-375^{\circ} \mathrm{C}$; Normand et al. [2002] with IGS $=250-500 \mathrm{~mm}$ and $T=300^{\circ} \mathrm{C}$; Seyfried et al. [2007] with IGS $=50-100 \mathrm{~mm}$ and $T=200^{\circ} \mathrm{C}$; and Okamoto et al. [2011] with IGS $<125 \mathrm{~mm}$ and $T=250^{\circ} \mathrm{C}$ ) have shown that olivine can remain present as a major phase after up to $8000 \mathrm{~h}$ in the $200-325^{\circ} \mathrm{C}$ range. This apparent inconsistency raises the question of the applicability of the synthetic forsterite reaction rates determined by Martin and Fyfe [1970] to ground peridotite.

[3] The above inconsistency served as an incentive to reinvestigate experimentally the kinetics of olivine serpentinization. The results of experiments on ground peridotite reacting with seawater [Marcaillou et al., 2011] as well as the serpentinization textures of abyssal peridotites [Bach et al., 2006; Frost and Beard, 2007; Beard et al., 2009], suggest that olivine hydration is the main serpentine-forming reaction, at least during the first stages of serpentinization. Therefore, we focused our kinetic study on olivine (as did Martin and Fyfe [1970]), and specifically chose natural ironbearing olivine (San Carlos olivine, $\mathrm{Fo}_{91}$ ) which is expected to exert a major control on the serpentinization kinetics of abyssal peridotites.

[4] In addition, we developed a new analytical tool to accurately determine the rate of olivine serpentinization. Magnetic quantification was used to monitor the amount of magnetite produced during Fe-bearing olivine hydration. We show in a companion paper [Malvoisin et al., 2012] that this method is capable of quantifying the amount of magnetite with a sensitivity on the order of $30 \mathrm{ppm}$. As anticipated with the experimental results by Moody [1976], Normand et al. [2002], and Seyfried et al. [2007], our new experiments yielded reaction rates that were orders of magnitude slower than those determined by Martin and Fyfe [1970] and Wegner and Ernst [1983] using synthetic forsterite. At the end of the experiments, the mineralogy and the morphology of the reaction products were characterized. In addition, statistical analyses of residual olivine morphologies were carried out using scanning electron microscopy (SEM) images in order to identify the processes governing the serpentinization of San Carlos olivine. Finally, the microstructures of olivine from serpentinized peridotite samples collected at the Southwest Indian Ridge (EDUL cruise) were characterized and compared to reacted olivine grains from our experiments.

\section{Methodology}

\subsection{Experimental and Analytical Methods}

[5] San Carlos olivine powder $\left(\mathrm{Fo}_{91}\right)$ was reacted either with deionized water or with an aqueous solution containing $33 \mathrm{~g} / \mathrm{L}$ of $\mathrm{NaCl}$ following the procedure described in the companion paper [Malvoisin et al., 2012]. The kinetics of the reaction were measured by using a high-sensitivity magnetic method that allows the retrieval of reaction progress from in situ saturation remanent magnetization measurements (see companion paper for details [Malvoisin et al., 2012]).

[6] Serpentine mineralogy was characterized by Raman microspectrometry using a Renishaw inVia spectrometer (ENS, Paris) with a $514.5 \mathrm{~nm}$ argon laser focused through a DM LM Leica optical microscope. The surfaces of residual olivine grains were cleaned ultrasonically to remove hydration products. They were subsequently mounted with double-sided carbon tape and characterized by field emission SEM (Zeiss- $\sum$ igma $^{\mathrm{TM}}$ equipped with a $50 \mathrm{~mm}^{2}$ EDS detector; X-Max ${ }^{\mathrm{TM}}$ from Oxford Instrument). A fraction of the run product was embedded in epoxy, and then cut and polished for the study of (1) mineral chemistry using energy dispersive X-ray (EDX) analyses and (2) textural relationships between reactant and products, as well as olivine grain size and morphology, using backscattered electron (BSE) imaging and image analysis.

[7] The image analysis was based on the derivation of morphological parameters of residual olivine grains (size, ellipticity and contour/surface ratio). These parameters were determined on polished mounts from statistical BSE image analysis on a population of 180 to 6000 grains (depending on grain size) and with a pixel size ranging from 0.15 to $1.5 \mu \mathrm{m}$. Pixels were automatically attributed to olivine grains on the basis of color correlation criteria. In particular, the entropyfilt function in Matlab was used to remove contributions from serpentine minerals that are close in color to olivine but which are morphologically more complex. The binary images were then segmented in order to associate pixels from the same grain. Finally, an ellipse was adjusted to each grain contour in order to retrieve both major $(a)$ and minor (b) ellipse semiaxes. The values obtained here were apparent values since they arose from two-dimensional geometrical properties obtained from grain sections. The relevance of the statistical analysis regarding the number of analyzed grains was checked using a numerical simulation for three populations of spheres (radii of 0.5, 5 and $20 \mu \mathrm{m}$ ) with different abundances (50, 10 and 1, respectively). The spheres were positioned randomly in 3-D space and cut along planes. In this simulation, morphological parameters were found to converge to $95 \%$ of their real value when using more than $\sim 200$ grain sections. The apparent ellipticity $(1-b / a)$ of each grain section and the apparent grain size $\left(D_{a p p}\right.$, calculated with the following formula: $D_{a p p}=$ 
Table 1. Experimental Conditions and Results ${ }^{\mathrm{a}}$

\begin{tabular}{|c|c|c|c|c|c|c|c|c|c|c|}
\hline Run & $\mathrm{m}$ Olivine & m Water & Initial Grain Size $(\mu \mathrm{m})$ & Temperature $\left({ }^{\circ} \mathrm{C}\right)$ & $\mathrm{NaCl}$ & Duration (h) & $\mathrm{S} \%$ & Polymorph & N Sections & $\mathrm{WMD}(\mu \mathrm{m})$ \\
\hline 1 & 155 & 62 & $100-150$ & 300 & & 3500 & $<1^{\mathrm{b}}$ & 1 & 223 & - \\
\hline 2 & 151 & 63 & $50-63$ & 300 & & 12300 & 80 & $\mathrm{~L}$ & 180 & - \\
\hline 3 & 164 & 63 & $100-150$ & 300 & $\mathrm{x}$ & 3400 & $<1^{b}$ & 1 & 264 & - \\
\hline 5 & 161 & 62 & $0-38$ & 300 & $\mathrm{x}$ & 1550 & 75 & $\mathrm{C} / \mathrm{L}$ & N.D. & - \\
\hline 6 & 156 & 62 & $0-38$ & 300 & & 1260 & $5.0^{\mathrm{c}}$ & $\mathrm{C} / 1$ & N.D. & - \\
\hline 7 & 167 & 61 & $38-50$ & 350 & & 6220 & 1 & $\mathrm{C}^{\mathrm{d}}$ & 1536 & 27.4 \\
\hline 8 & 156 & 60 & $38-50$ & 350 & & 2580 & 1 & $C^{d}$ & 581 & 37.8 \\
\hline 10 & 156 & 61 & $38-50$ & 300 & & 6020 & 38 & $\mathrm{~L}$ & 3189 & 24.0 \\
\hline 11 & 157 & 61 & $38-50$ & 270 & & 5960 & 32 & $\mathrm{~L}$ & 3896 & 30.3 \\
\hline 12 & 153 & 61 & $38-50$ & 250 & & 5180 & 26 & $\mathrm{~L}$ & 4089 & 33.2 \\
\hline 16 & 157 & 61 & $5-15$ & 300 & & 1800 & 30 & $\mathrm{~L}$ & 5167 & 7.4 \\
\hline 17 & 158 & 60 & $5-15$ & 300 & & 215 & 8.5 & $\mathrm{c}$ & 3716 & 7.3 \\
\hline 20 & 156 & 60 & $5-15$ & 300 & & 1800 & 68 & $\mathrm{~L}$ & 5932 & 6.7 \\
\hline 21 & 160 & 61 & $5-15$ & 300 & & 600 & 18 & $\mathrm{c} / 1$ & 4690 & 7.0 \\
\hline 22 & 160 & 61 & $5-15$ & 300 & & 1760 & 89 & $\mathrm{~L}$ & 5237 & 6.2 \\
\hline 24 & 158 & 61 & $1-5$ & 300 & & 2390 & 91 & $\mathrm{C}$ & N. D. & - \\
\hline 25 & 157 & 59 & $5-15$ & 270 & & 1470 & 58 & $\mathrm{~L}$ & 5701 & 7.3 \\
\hline
\end{tabular}

${ }^{a}$ Abbreviations are as follows: $\mathrm{m}$ Olivine, initial mass of olivine (mg); $\mathrm{m}$ Water, initial mass of water (mg); $\mathrm{NaCl}$, presence or absence of $\mathrm{NaCl}$ in the starting fluid; S\%, reaction progress; polymorph, serpentine polymorph ( $\mathrm{C}$ and $\mathrm{c}$ for chrysotile as major and minor species, respectively, and $\mathrm{L}$ and 1 for lizardite as major and minor species); $\mathrm{N}$ sections, number of sections across olivine grains for the statistical analysis; WMD, weighted mean diameter of the residual olivine grains; N.D., not determined.

${ }^{\mathrm{b}}$ Estimation using backscattered electron images.

${ }^{c}$ Reaction progress determined using infrared spectroscopy on powder sample [Malvoisin et al., 2012].

${ }^{\mathrm{d}}$ Results from scanning electron microscopy morphological observations due to small amount of reaction products.

$\left.\operatorname{sqrt}\left(a^{*} b\right)\right)$, were calculated both from the major and minor ellipse semiaxes ( $a$ and $b$, respectively) derived from image analysis. For a single grain, it should be noted that the mean of $D_{a p p}\left(\bar{D}_{a p p}\right)$ is not equal to the real grain size $(D)$ which is underestimated because sections mainly do not crosscut the grain along its main section. For example, for a sphere, $\bar{D}_{a p p}=\frac{\pi}{4} \cdot D$. Moreover, considering a given population of grains, both the abundance of grains with the same size and their corresponding radii, will influence the probability that they will be crosscut and, consequently, the value of $\bar{D}_{a p p}$. The ratio between the contour and surface area $(C / S)$ for each grain section which strongly depends on grain size, was also measured. $C / S$ is also an apparent value which depends on the grain size distribution within the investigated population. Even though $D_{a p p}$ and the $C / S$ ratio are apparent parameters, they relate to real parameters, and thus they were used to track the evolution of the grain geometries.

[8] The dissolution kinetics of olivine were modeled using the geochemical code CHESS [van der Lee and De Windt, 2002] which in turn used the thermodynamic database chess.tdb, derived from the Lawrence Livermore National Laboratories equation 3/6 database.

\subsection{Natural Samples}

[9] Two samples (EDUL-DR25-3-1 and EDUL-DR25-7-5) of moderately serpentinized harzburgite dredged at $28.88^{\circ} \mathrm{S}$ and $61.94^{\circ} \mathrm{E}$ from the Southwest Indian Ridge during the EDUL cruise [Mével et al., 1997] were selected in order to compare our experimental results to serpentinized oceanic peridotites. The Southwest Indian Ridge has a very low spreading rate of $\sim 14 \mathrm{~mm} / \mathrm{yr}$ [DeMets et al., 1994] and a low magma supply resulting in widespread exposure of variably serpentinized mantle rocks [Dick et al., 2003; Cannat et al., 2006]. We analyzed olivine morphologies in thin sections from these two samples using FE-SEM, in the same manner as for the experimentally altered olivine grains.

\section{Results}

[10] Seventeen experiments were performed at 500 bars at temperatures between 250 and $350^{\circ} \mathrm{C}$. IGS of San Carlos olivine ranged between 1 and $150 \mu \mathrm{m}$ (Table 1). Experiments ranged from 200 to $12,000 \mathrm{~h}$ and up to twenty four magnetic measurements were performed during each experiment. A large range of reaction progress was examined, ranging from 1 to $90 \%$. Finally, a rate law for olivine serpentinization which depends on both IGS $(>5 \mu \mathrm{m})$ and temperature is given in Appendix A.

\subsection{Mineralogy of the Reaction Products}

[11] In all of the experiments the reaction products were composed of serpentine, brucite and magnetite. Magnetite sizes ranged from less than $1 \mu \mathrm{m}$ up to $20 \mu \mathrm{m}$ (Figure 1a). The coarser grains were euhedral in runs 5, 6 and 24 whereas in the other runs the large grains were aggregates of smaller grains (see companion paper for details [Malvoisin et al., 2012]). Moreover, the magnetic properties of magnetite indicate a better crystallinity in runs conducted on the smaller IGS (runs 5, 6 and 24 [Malvoisin et al., 2012]). Raman spectra collected on serpentine aggregates show a series of bands at $240 \mathrm{~cm}^{-1}, 3688 \mathrm{~cm}^{-1}$, and $3703 \mathrm{~cm}^{-1}$, and/or at $230 \mathrm{~cm}^{-1}, 3699 \mathrm{~cm}^{-1}$, and $3685 \mathrm{~cm}^{-1}$, which indicates the presence of lizardite and/or chrysotile, respectively [Lemaire et al., 1999; Auzende et al., 2004] (Table 1). Chrysotile occurred as fibers of $\sim 10 \mathrm{~nm}$ in diameter, whereas lizardite had a micrometer size and exhibited a tabular or spherical habitus (Figures 1c and 1d). Chrysotile mainly occurred in experiments with the smaller IGS $(5 \mu \mathrm{m}$ or less, i.e., runs 5, 6 and 24, Table 1). Brucite was euhedral with abundant cleavage planes and with grain sizes ranging from 10 to $100 \mu \mathrm{m}$ (Figure 1a). Residual olivine from the 

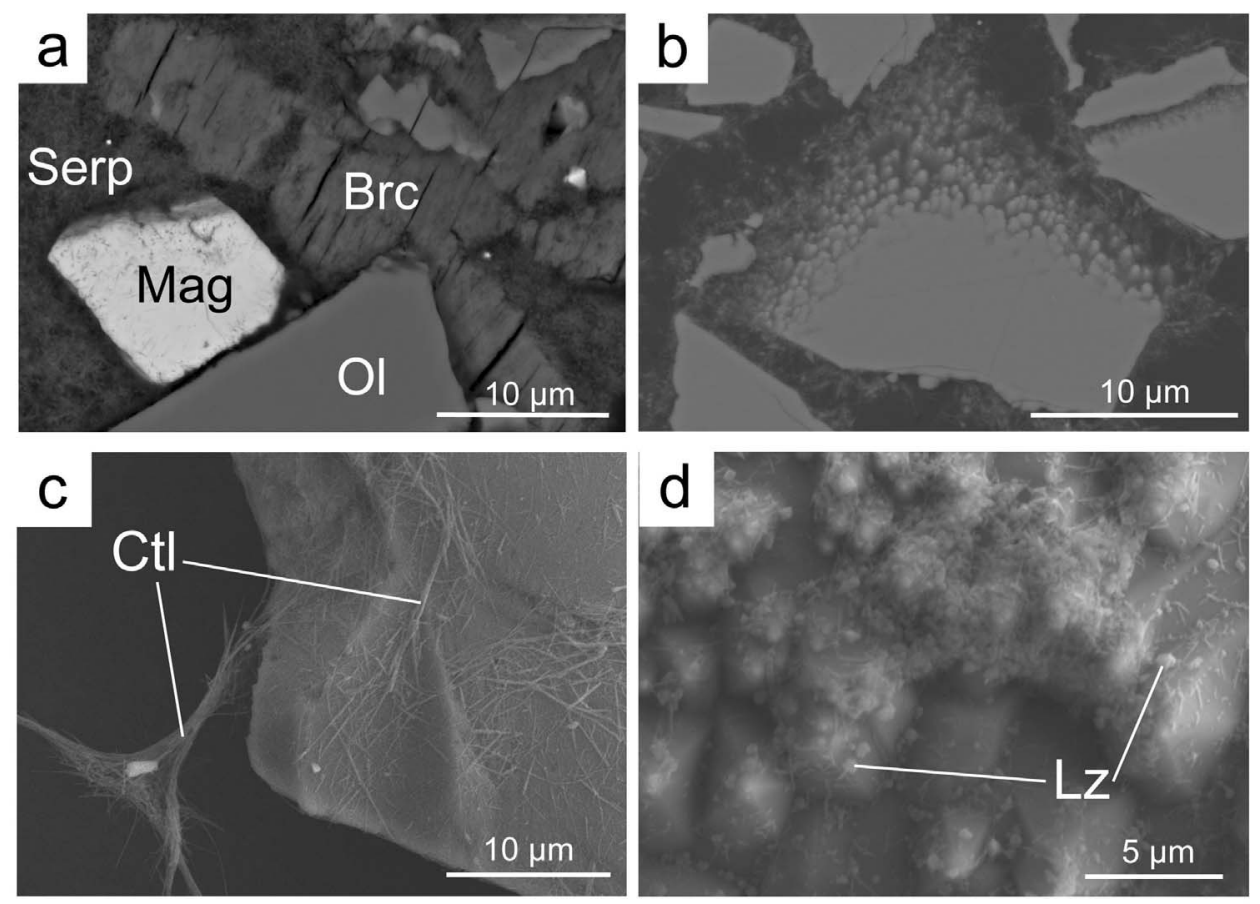

Figure 1. Scanning electron microscopy images of reacted powders: backscattered electron (BSE) images of polished sections for Figures $1 \mathrm{a}$ and $1 \mathrm{~b}$ and secondary electron (SE) images of olivine grains surfaces for Figures 1c and 1d. (a) Polished section of reaction products (run 5). Brucite (Brc) has a tabular morphology with distinct cleavage planes. Magnetite (Mag) appears slightly porous. (b) Cross section of an olivine grain from run 21 showing that the section across a surface with etch pits is equivalent to a section through submicrometric isolated grains. However, these grains are artificial and only arise from 2-D observation. (c) Run 7 with chrysotile (Ctl) fibers. (d) Run 11 with formation of less elongated/spherical lizardite (Lz). Mineral abbreviations are from Kretz [1983].

most reacted samples ( $>85 \%$ reaction progress) was apparently armored by brucite, possibly resulting in its isolation from the bulk solution.

[12] The distribution of iron between the magnetite and hydrous minerals (serpentine and brucite) was investigated through magnetic and EDX measurements in conjunction with thermochemical modeling [Malvoisin et al., 2012]. Iron was preferentially incorporated into magnetite with increasing temperature, and was exclusively hosted by magnetite at $350^{\circ} \mathrm{C}$.

\subsection{Reaction Progress Versus Time Curves}

[13] When reaction progress is plotted as a function of time for experiments that were run to near completion (e.g., runs 2, 22 and 24, Figure 2a), the corresponding curves display an overall sigmoidal form that can be divided into three domains (labeled I, II and III in Figures 2a and 2b) that correspond to distinct reaction kinetic regimes. An initial, very rapid kinetic reaction stage (zero stage) is observed in a majority of the experiments (Figure 2); see in particular runs 7 and 8 (Figure 2d). This zero stage is interpreted as an artifact because of the presence of submicrometric particles remaining in the starting olivine powder. This effect is more pronounced for small olivine IGS: this initial reaction stage represents $\sim 5 \%$ of the total reaction extent for IGS of 5$15 \mu \mathrm{m}$ (Figure $2 \mathrm{~b}$, run 22), but it is not observed for grain sizes of $100-150 \mu \mathrm{m}$ (Figure $2 \mathrm{~d}$, runs 1 and 3 ). The serpentinization rate during this initial stage approaches $0.085 \%$ per hour for run 22 (IGS $5-15 \mu \mathrm{m}$ ).

[14] In the first stage (I), $20-25 \%$ of the reaction is achieved. This stage lasted only $275 \mathrm{~h}$ for small IGS (5$15 \mu \mathrm{m}$; e.g., run 22) and up to $9000 \mathrm{~h}$ for larger IGS (50 $63 \mu \mathrm{m}$; e.g., run 2). These correspond to serpentinization rates of 0.065 and $0.003 \%$ per hour, respectively.

[15] The second stage (II), which accounts for $\sim 40 \%$ of the reaction, reveals the highest serpentinization kinetics: 0.15 and $0.016 \%$ per hour for runs $22(5-15 \mu \mathrm{m})$ and $2(50$ $63 \mu \mathrm{m})$, respectively.

[16] Finally, the reaction rates progressively decrease during the third stage (III) to rates that tend to zero as the reactions approach completion. Taken together, the three stages identified here define a sigmoidal function that recalls an Avrami-type kinetics law (see Appendix A).

\subsection{Reaction Rate as a Function of Grain Size}

[17] The serpentinization kinetics are strongly grain-size dependent, with higher serpentinization rates for the smallest grain sizes (Figures $2 \mathrm{~b}$ and $2 \mathrm{~d}$ ). For example, after $2000 \mathrm{~h}$ of reaction at $300^{\circ} \mathrm{C}$ and 500 bars, the reaction extent is of $89 \%$ for run 22 (IGS of 5 to $15 \mu \mathrm{m}$ ) and of only $\sim 0.3 \%$ for run 1 (IGS 100 to $150 \mu \mathrm{m}$ ). Similarly, $35 \%$ of reaction extent is achieved within 400,6000 and $9400 \mathrm{~h}$ for IGS of 5-15, 3850 and $50-63 \mu \mathrm{m}$, respectively. This latter observation shows that the serpentinization kinetics for IGS $\geq 5 \mu \mathrm{m}$ is 

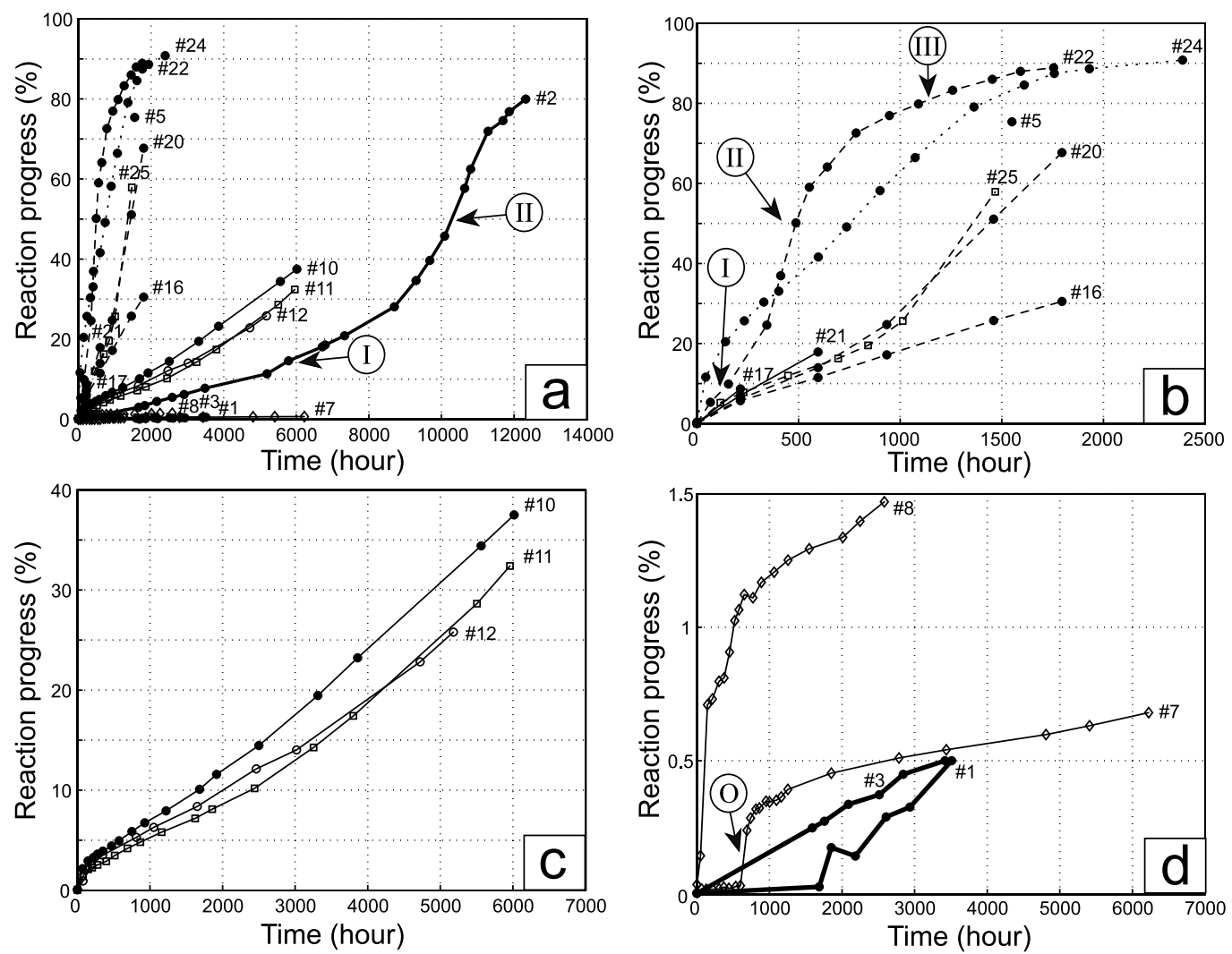

Initialal grain sizze:

..... : 1-5 $\mu \mathrm{m}$

- - . . : 5-15 $\mu \mathrm{m}$

- $38-50 \mu \mathrm{m}$

- : 50-63 $\mu \mathrm{m}$

- $: 100-150 \mu \mathrm{m}$

Temperature:

○ : $250^{\circ} \mathrm{C}$

ㅁ $: 270^{\circ} \mathrm{C}$

- : $300^{\circ} \mathrm{C}$

$\diamond: 350^{\circ} \mathrm{C}$

Figure 2. Magnetic monitoring of the olivine serpentinization reaction: kinetic data. The kinetic curves have been divided into four stages (O, I, II, and III); see text. (a) Survey of all the experiments for comparison. Note that run $2\left(300^{\circ} \mathrm{C}\right.$, initial grain size (IGS) of 50-63 $\left.\mu \mathrm{m}\right)$ lasted about a year and a half. (b) Experiments with small IGS (1-5 $\mu \mathrm{m}$ for run 24, 0-38 $\mu \mathrm{m}$ for runs 5 and 6, and 5-15 $\mu \mathrm{m}$ for all the others runs). (c) Effect of temperature for a given IGS $(38-50 \mu \mathrm{m})$ at 250,270 , and $300^{\circ} \mathrm{C}$ for runs 12 , 11, and 10, respectively. (d) Limited reaction progress at $300^{\circ} \mathrm{C}$ for IGS of $100-150 \mu \mathrm{m}$ (runs 1 and 3) and $350^{\circ} \mathrm{C}$ for IGS of $38-50 \mu \mathrm{m}$ (runs 7 and 8), respectively.

inversely proportional to the square of the IGS (i.e., to the initial grain surface).

[18] The kinetics of run 24 (IGS of $1-5 \mu \mathrm{m}$ ) and 22 (IGS of $5-15 \mu \mathrm{m})$ are found to be comparable (Figure 2b). Therefore, the inverse squared relationship between serpentinization rate and IGS no longer holds for IGS $<5 \mu \mathrm{m}$, although the general sigmoidal shape of the reaction progress time curve is independent of the IGS.

\subsection{Influence of Temperature and $\mathrm{NaCl}$ on Serpentinization Kinetics}

[19] In order to study the effect of temperature (at 500 bars) on olivine hydration kinetics (Figures $2 \mathrm{c}$ and $2 \mathrm{~d}$ ), we performed a series of experiments with IGS in the 38 $50 \mu \mathrm{m}$ range at temperatures of $250^{\circ} \mathrm{C}$ (run 12 ), $270^{\circ} \mathrm{C}$ (run 11), $300^{\circ} \mathrm{C}$ (run 10) and $350^{\circ} \mathrm{C}$ (run 7 and 8: the results of these two runs are averaged for the kinetic analysis). None of these experiments reached completion (Figures 2c and 2d). During Stage I, the reaction rates calculated assuming a linear progress of the reaction, are found to equal $4.91,5.96,6.86$ and $0.15 \%$ per $10^{3} \mathrm{~h}$ for experiments carried out at $250^{\circ} \mathrm{C}, 270^{\circ} \mathrm{C}, 300^{\circ} \mathrm{C}$ and $350^{\circ} \mathrm{C}$, respectively. These rates show an asymmetric bellshaped curve dependency as a function of temperature. The highest reaction kinetics are achieved at $\sim 300^{\circ} \mathrm{C}$, that is, at the bell curve maximum (see Appendix A).

[20] Experiments conducted with $\mathrm{NaCl}$ (runs 3 and 5) yielded kinetics that are comparable to those measured for the experiments conducted in pure water. Consequently, the influence of $\mathrm{NaCl}$ on the kinetics is of second order in comparison to the effect of grain size and temperature.

\subsection{Microstructures of Olivine in Experimental Samples: Dissolution and Fracturing}

[21] Examination of unreacted olivine grains by SEM shows that some grains display a few fractures. SEM images of residual olivine grains in the run products shows a much higher density of cracks. These cracks are clearly visible on secondary electron images since they were the locus of enhanced dissolution (Figure 3a). Cracks cutting through the olivine grains are also observed on polished sections; in some instances, they split the grains into independent domains (Figure 3b). Grain splitting could result from a hierarchical fracturing of the grains where newly created surfaces were exposed to dissolution, and then refractured. It cannot be excluded that fracturing preferentially occurred at preexisting cracks (crushed olivine) which were not necessarily observed by SEM. 

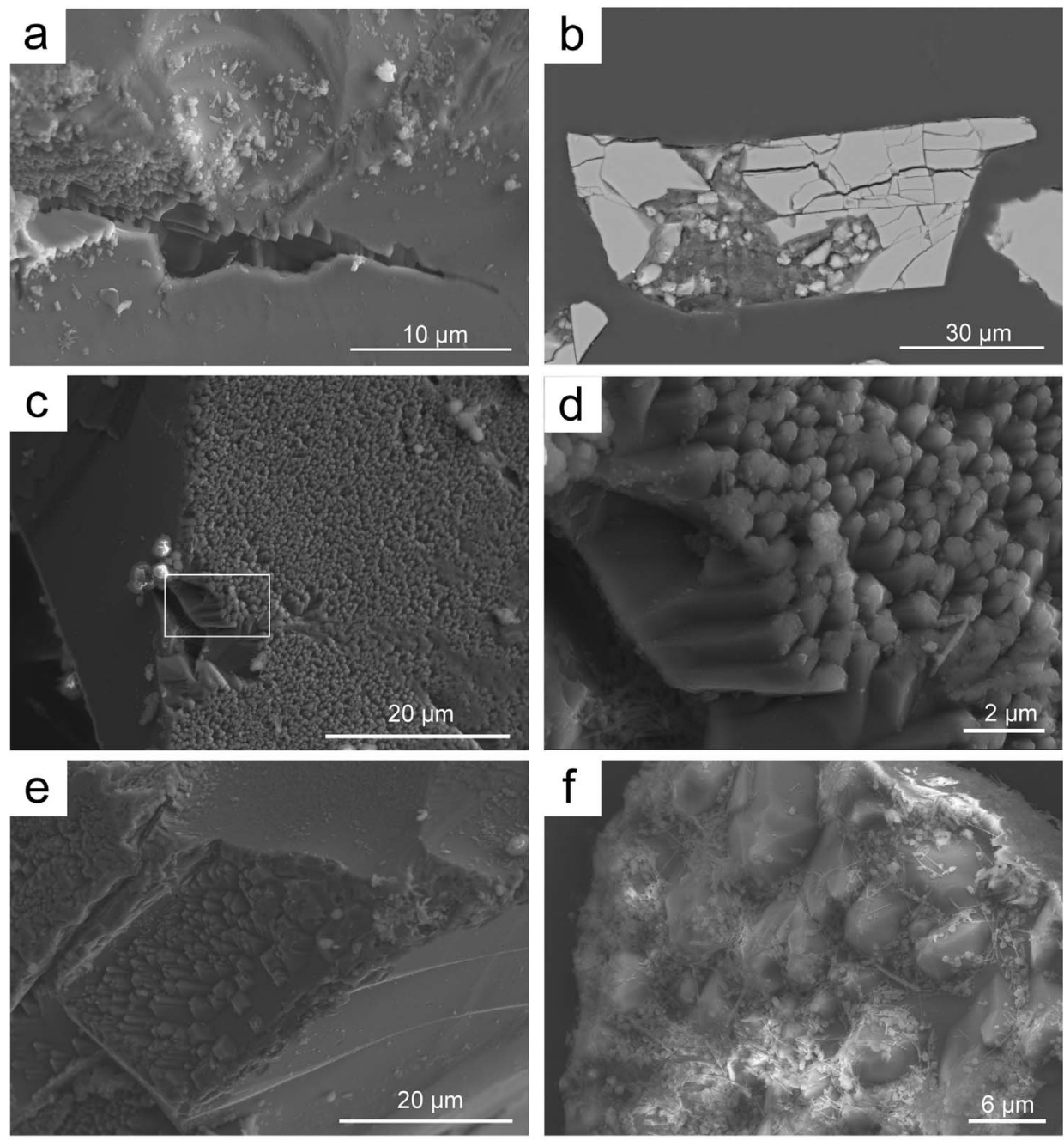

Figure 3. Microstructures of reacted olivine: cracks in Figures $3 a$ and $3 b$ and etch pits in Figures $3 c, 3 d$, 3e, and 3f. (a) Etch pits on a fracture surface in run 1. (b) Highly fractured grain from run 7. The fracture distribution is consistent with hierarchical fracturing. Note that the main olivine grain is replaced in its center with reaction products. (c and d) Polyhedral surface features corresponding to deep etch pits (run 1). (e) Pyramidal etch pits (run 1). Note that in Figures 3c and 3e etch pits do not develop on every olivine surface. (f) Mammillated surface features (run 11). Note that serpentine is still present at the grain surface despite ultrasonic treatment.

[22] Detailed inspection of grain surfaces after ultrasonic cleaning (Figures 3c, 3d, 3e and 3f) shows two types of surface roughness. Some olivine surfaces are smooth and devoid of any visible dissolution features at the submicrometric scale. Others surfaces are characterized by the presence of abundant etch pits (Figures $3 a$ and $3 b$ ). These dissolution features evolve, with increasing reaction progress, from isolated conical etch pits to network of polyhedral, and pyramidal mounts (Figures 3a, 3b and 3c). Ultimately, the olivine surface displays a mammillated (sawtooth) topography (typically for reaction progresses greater than $\sim 20 \%$ (Figure 3d) [Gravenor and Leavitt [1981]). These topographical features have dimensions that attain $10 \mu \mathrm{m}$. From a geometrical point of view, mammillated surfaces can be approximated as a network of pyramids with amplitudes of 2.5 to $5 \mu \mathrm{m}$, with square bases $5 \mu \mathrm{m}$ on a side. On the basis of this, the formation of these structures results in a theoretical increase in surface area of $\sim 200$ to $300 \%$.

\subsection{Morphological Analysis of Olivine From SEM Images}

[23] Etch pit cross sections artificially produce numerous small olivine grains with sizes $\sim 1 \mu \mathrm{m}$ (Figure 1b). As a consequence, two populations of apparent olivine grains with distinct sizes are observed in thin sections of samples where etch pits were formed: grains with sizes comparable to the IGS and submicrometric grains attributed to crosscut etch pits. Figure 4 shows that these two populations are observed in nearly all of the experiments. In experiments with the larger IGS (runs 10, 2, 7 and 8), a third population of grains was found with sizes intermediate between etch pit-associated sizes $(\sim 1 \mu \mathrm{m})$, and IGS. For experiments 


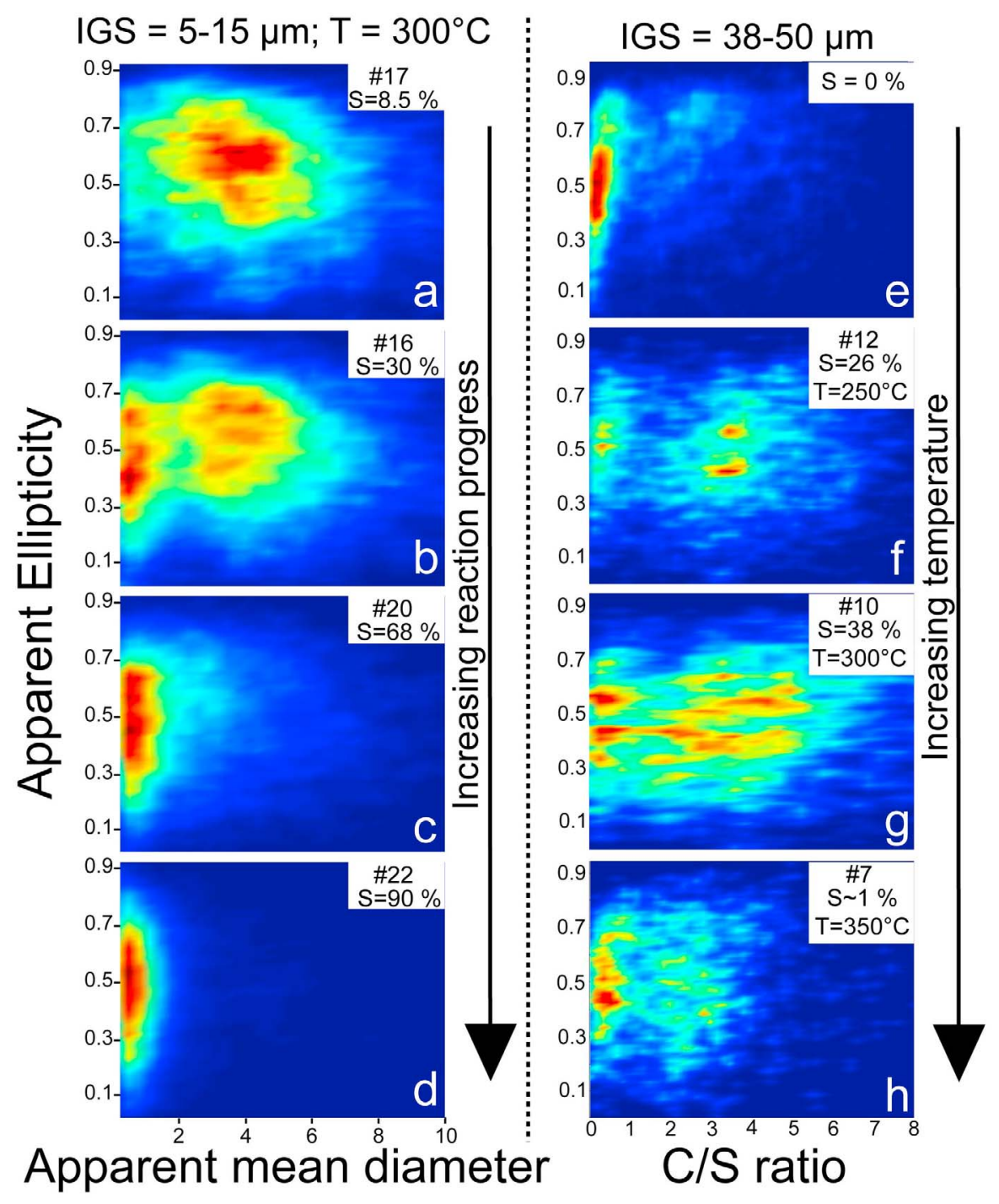

Figure 4. Density diagram of apparent ellipticity as a function of the apparent mean diameter $\left(\bar{D}_{a p p}\right)$ or of the apparent contour/surface area ratio $(\mathrm{C} / \mathrm{S})$ obtained after statistical analysis of olivine sections from BSE images. S and T refer, respectively, to reaction progress and run temperature. (a-d) Ellipticity versus $\bar{D}_{a p p}$ for runs $7,16,20$, and 22 with increasing reaction progress. A decrease in the grain size is observed and, notably, the formation of grains with two distinctive sizes (clearly visible on Figure 4b). (e-f) Ellipticity versus apparent $\mathrm{C} / \mathrm{S}$ for IGS of $38-50 \mu \mathrm{m}$ (runs $8,12,10$, and 7). C/S retrieved from image analysis as a proxy of the grain size. Compared to $\bar{D}_{a p p}, \mathrm{C} / \mathrm{S}$ tends to cluster the grains of larger diameter and yields a better graphical representation of the grain size distribution for small IGS.

having an IGS of $38-50 \mu \mathrm{m}$, the mean apparent grain diameter $\left(\bar{D}_{a p p}\right)$ is $21 \mu \mathrm{m}$ in run 8 whereas it decreases to $7 \mu \mathrm{m}$ for run 7 which lasted 2.5 times longer. Olivine grains of run 7 appear to be highly fractured (Figure 3b). Fracturing could be responsible for the grain size decrease observed in this run (and in run 10, Figure 4g).

[24] The role of fracturing in creating new reactive surface area was investigated by examining its effect on serpentinization kinetics $(\zeta=f(t)$, Figure 5) retrieved for run $2(50$ $63 \mu \mathrm{m})$, run $10(38-50 \mu \mathrm{m})$ and run $22(5-15 \mu \mathrm{m})$. As a first-order approximation, the kinetics were found to be inversely proportional to the initial surface area (section 3.2). Consequently, to study second-order effects on the reaction kinetics, the rate of serpentinization $\left(\frac{\partial \zeta}{\partial t}\right)$ was normalized to the initial specific surface area calculated from the IGS assuming spherical grains. It was then plotted as a function of $\zeta$ (Figure $5 \mathrm{~b}$ ). The corresponding curves display a bell shape consistent with the sigmoidal shape of the $\zeta=f(t)$ function (Figure 5). The maximum normalized rate of run 2 is five times greater than that of run 22 . This difference can be interpreted as the effect of fracturing in run 2 which involved larger olivine grains.

[25] In order to quantify the effect of grain fracturing on the creation of new reactive surface area, the mean diameter of residual olivine grains (Table 1) was compared to the 

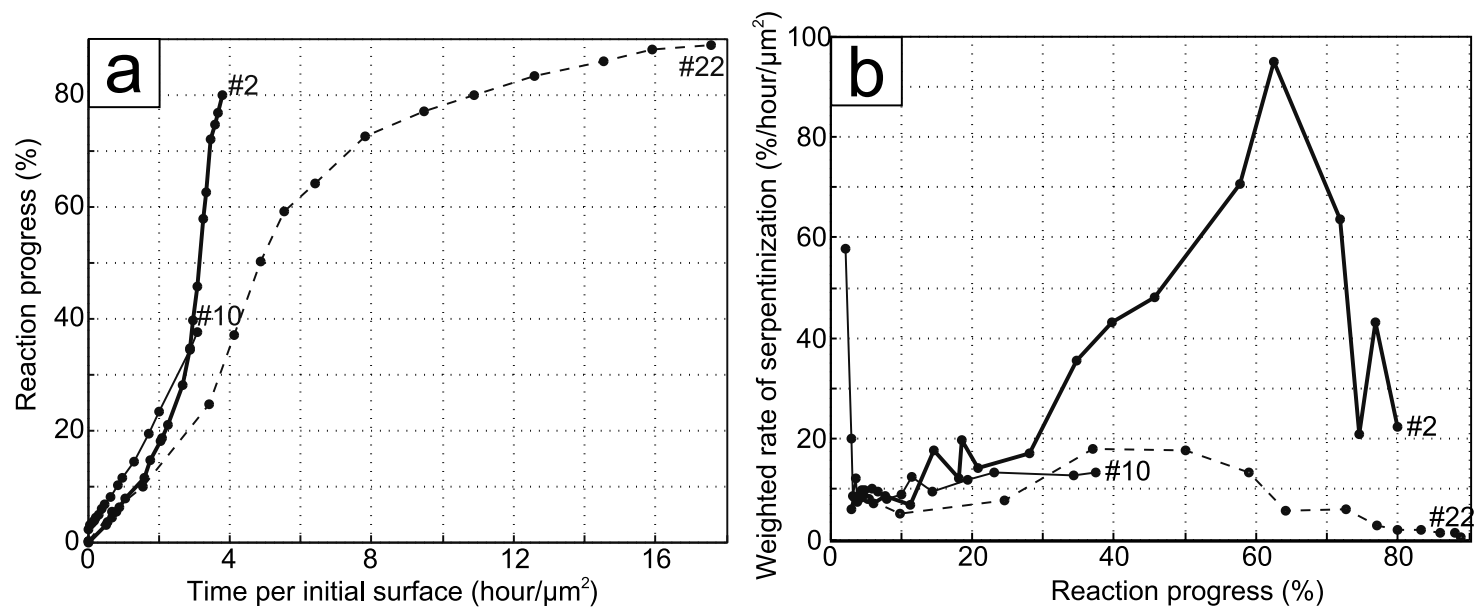

Figure 5. Comparison of kinetics of serpentinization normalized to the initial grain surface. Numbers 2, 10 , and 22 refer to run $2(50-63 \mu \mathrm{m})$, run $10(38-50 \mu \mathrm{m})$, and run $22(5-15 \mu \mathrm{m})$, respectively. (a) Reaction progress as a function of time per olivine grain surface area. (b) Rate of serpentinization (\% reaction/ hour $\left./ \mu \mathrm{m}^{2}\right)$ as a function of reaction progress (\%).

mean grain diameter of the unreacted powder. A weighted mean of the grain diameter (WMD) was used to remove the contribution of artifact grains associated with etch pit cross sections. For small IGS $(5-15 \mu \mathrm{m}$, initial WMD $=7.3 \mu \mathrm{m})$, the smallest WMD is $6.2 \mu \mathrm{m}$ for an experiment having reached $89 \%$ reaction extent (run 22). This decrease is small and can be merely accounted for by mineral dissolution alone. In experiments with larger IGS $(38-50 \mu \mathrm{m}$, initial $\mathrm{WMD}=37.6 \mu \mathrm{m})$, however, a stronger decrease in WMD is observed. WMD drops by $27 \%$ in run 7 that is characterized by $\sim 1 \%$ reaction progress. Considering this very low reaction progress, the decrease in WMD in run 7 cannot be attributed to mineral dissolution only, and grain fracturing must be the dominant grain size reduction process.

\subsection{Microstructure of Serpentinized Peridotite Samples From the Southwest Indian Ridge}

[26] Two samples with a typical serpentine mesh texture were studied. The olivine composition determined with EDX is $\mathrm{Fo}_{90.5}-\mathrm{Fo}_{91}$. The degree of serpentinization deduced from image analysis on $\sim 1 \mathrm{~mm}^{2}$ olivine-rich domains, is $83 \% \pm 3 \%$ and $80 \pm 3 \%$ in samples EDUL-DR25-3-1 and EDUL-DR25-7-5, respectively. The serpentine mesh surrounding the olivine relicts is consistent with literature descriptions of partially serpentinized abyssal peridotites [Dilek et al., 1997; Andreani et al., 2007]. It is characterized by fractures filled with lizardite (determined on the basis of Raman spectra) which separate and partition the original olivine grains. The contact between olivine and serpentine is either sharp or displays indentations, 1 to $10 \mu \mathrm{m}$ in size (Figure 6b), similar to those observed in our experimental products (Figure 6a). They are interpreted, following Velbel [2009], as mammillated surfaces related to etch pit formation.

\section{Discussion}

\subsection{The Rate Limiting Processes}

[27] In our experiments, the serpentinization rate is found to be proportional to the geometric surface area of the starting material olivine down to an initial grain size of $\sim 5 \mu \mathrm{m}$. Residual olivine surfaces display dissolution features, the size and the morphology of which evolve with serpentinization progress. This strongly suggests that olivine dissolution was the rate-limiting process for serpentinization in our experiments. To test this interpretation, the kinetic data retrieved for these experiments were compared to simulations of olivine dissolution at $300^{\circ} \mathrm{C}$ and 500 bars using dissolution rates from the literature [Wogelius and Walther, 1992; Blum and Lasaga, 1988; Pokrovsky and Schott, 2000; Chen and Brantley, 2000; Rosso and Rimstidt, 2000; Oelkers, 2001; Hänchen et al., 2006]. For these simulations, we used the CHESS code [van der Lee and De Windt, 2002] and an initial surface area of olivine determined using either a geometrical approximation (spherical grains of fixed diameter: $57 \mu \mathrm{m}$ ) or an estimated BET area based on a BET grain diameter correlation determined by Brantley and Mellott [2000]. These simulations all yielded dissolution kinetics that are orders of magnitude higher than the olivine serpentinization kinetics determined in the present study (Figure 7). This inconsistency may arise from errors due to extrapolating rates determined at far-from-equilibrium conditions at 25 to $150^{\circ} \mathrm{C}$ to near-equilibrium conditions at $300^{\circ} \mathrm{C}$.

[28] For initial grain sizes below $5 \mu \mathrm{m}$ (runs 5, 6 and 24), the linear relationship between serpentinization kinetics and initial surface area is no longer observed (Figure 2b). Reaction products are also different since (1) chrysotile was produced instead of lizardite (Table 1) and (2) the morphology and magnetic properties of magnetite indicate a higher degree of crystallinity for this mineral product [Malvoisin et al., 2012]. The reaction process is therefore different when starting with olivine grains smaller than $5 \mu \mathrm{m}$. Our interpretation is that olivine dissolution is no longer the rate limiting process. It has been shown that chrysotile crystallization (at $300^{\circ} \mathrm{C}$ ) requires a higher degree of supersaturation than lizardite crystallization [Grauby et al., 1998; Normand et al., 2002]. This would indicate an increase of the solution supersaturation in our 

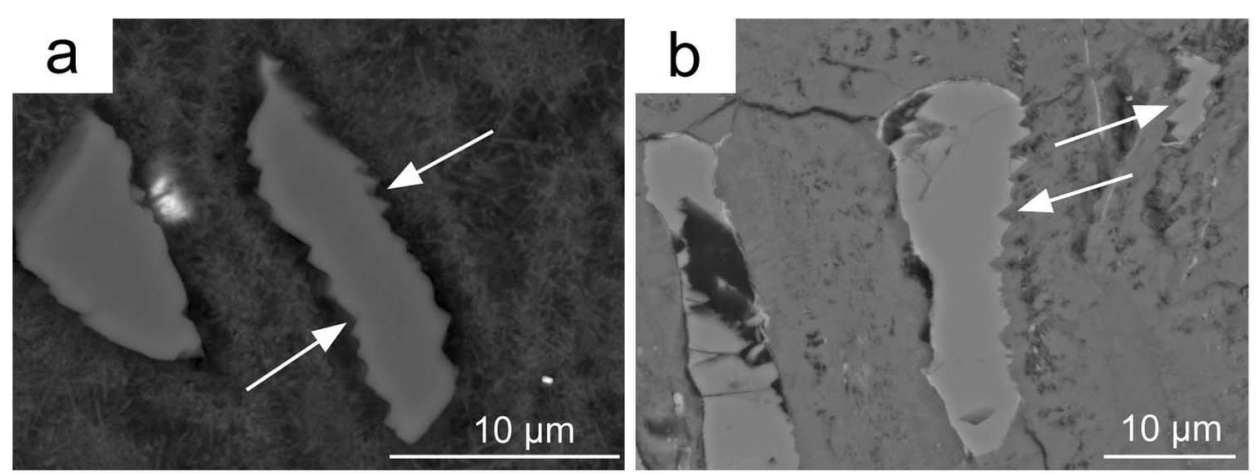

Figure 6. BSE images of thin sections across residual olivine grains in experimental products from (a) run 5 and in (b) serpentinized abyssal peridotite sample EDUL_DR25-03-01. Arrows point toward the jagged contours of olivine grains. These indentations are interpreted as cross sections of mammillated etch pits [Velbel, 2009] similar to those shown on olivine grain surfaces in Figure 4.

experiments because of high olivine dissolution rates for IGS less than $5 \mu \mathrm{m}$.

[29] Some residual olivine grains are found to be armored by brucite in experiments that exceeded $85 \%$ reaction progress. This armoring is also observed in natural samples [Klein et al., 2009] and may become a rate limiting process at high degrees of reaction progress.

\subsection{Comparison of Our Kinetic Law With Data From Previous Studies}

[30] The kinetics data obtained here are compared to experimental data in the literature (Figure 7). Our results are in good agreement with the results of experiments performed on ground peridotite samples with seawater [Seyfried et al., 2007; Marcaillou et al., 2011]. Serpentinization experiments

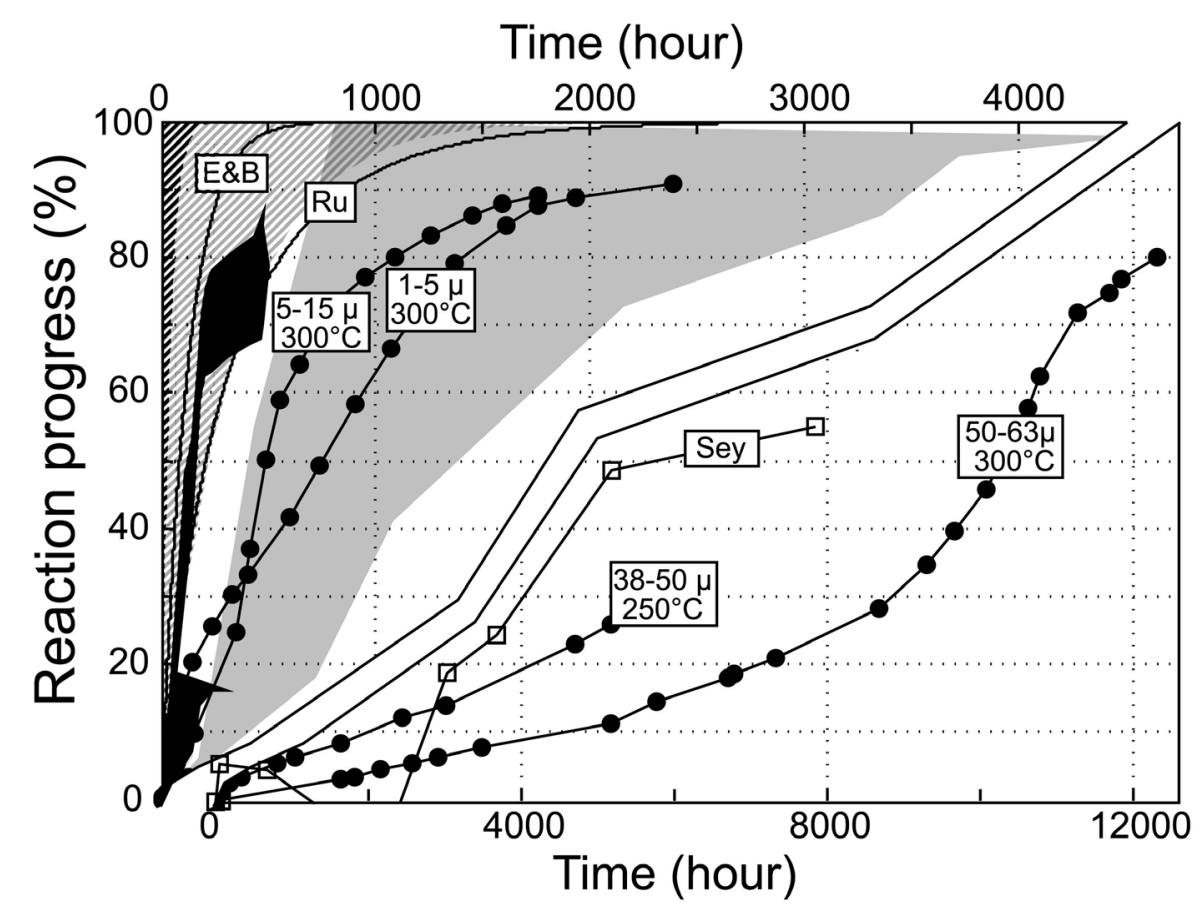

Figure 7. Comparison between serpentinization kinetic data from this study and from the literature. The conditions of our experiments (IGS and temperature) are indicated on the curves. The hatched areas (top left) correspond to modeled dissolution of olivine using CHESS. Two configurations of the reactive surface area for IGS of $57 \mu \mathrm{m}$ are considered: BET-derived surface area (black) and geometric surface area (grey); see details in text. Black area refers to data for synthetic forsterite powders between 210 and $245^{\circ} \mathrm{C}$ from the work of Martin and Fyfe [1970]. Ground natural peridotite with IGS of 50-100 $\mu \mathrm{m}$ at $200^{\circ} \mathrm{C}$ is from the work of Seyfried et al. [2007] (squares and "Sey") and with IGS of $\sim 1 \mu \mathrm{m}$ at $300 \pm 50^{\circ} \mathrm{C}$ from Marcaillou et al. [2011] and Marcaillou [2011] (grey area). The kinetic law used in numerical modeling by Emmanuel and Berkowitz [2006] ("E\&B") and Rudge et al. [2010] ("Ru") is also reported for IGS of $57 \mu \mathrm{m}$. 


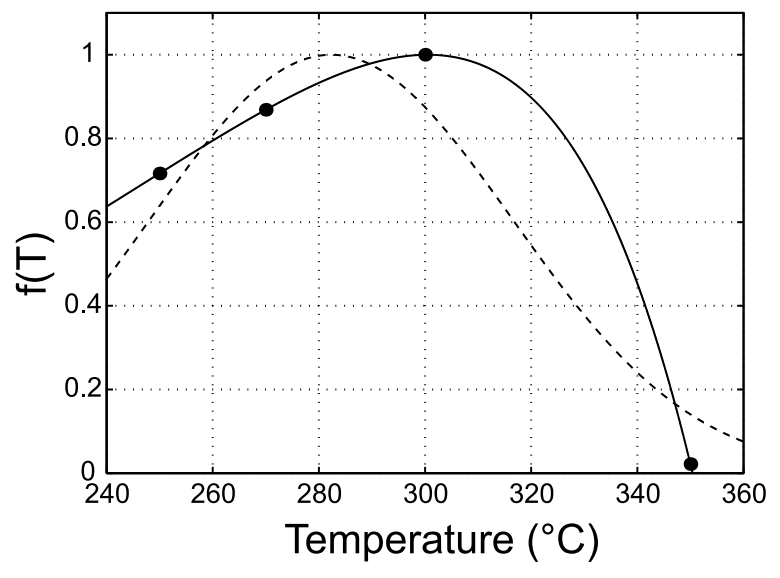

Figure A1. Temperature dependence of the reaction kinetics ( 1 for maximum rate and 0 for no reaction). Solid circles are data for runs $7,8,10,11$, and 12 . The solid line is function $f_{1}$ and the dashed line is function $f_{2}$ (see text).

of Marcaillou et al. [2011] were performed on fine initial grains $(\sim 1 \mu \mathrm{m})$ and reaction completion was achieved after 2 months at $300^{\circ} \mathrm{C}$. This is in very good agreement with rates derived from our experiment with the smallest IGS $(1-5 \mu \mathrm{m})$ that reached completion after $\sim 2.5$ months (run 24) and for which olivine dissolution was not the rate-limiting factor. Serpentinization experiments of Seyfried et al. [2007] were performed on peridotite at $200^{\circ} \mathrm{C}$ and 500 bars with IGS from 50 to $100 \mu \mathrm{m}$, and did not reach completion after $8000 \mathrm{~h}$. This is also in good agreement with our experiments with IGS of 38-50 $\mu \mathrm{m}$ and 50-63 $\mu \mathrm{m}$ (Figure 7). Furthermore, Marcaillou et al. [2011] and Seyfried et al. [2007] showed (1) that olivine is the most abundant phase in their powder peridotite sample ( $76 \mathrm{~mol} \%$ and $62 \mathrm{vol} \%$, respectively). Marcaillou et al. [2011] and Okamoto et al. [2011] also showed (2) that natural olivine reacts faster than pyroxene with seawater at $300^{\circ} \mathrm{C} / 300$ bars and deionized water at $250^{\circ} \mathrm{C} /$ vapor-saturated pressure, respectively. These are the reasons why data collected on olivine hydration (this study) are in accord with data acquired on ground natural peridotite samples at temperatures between 200 and $350^{\circ} \mathrm{C}$.

[31] The most extensively used serpentinization rate law is that of Martin and Fyfe [1970] [e.g., Allen and Seyfried, 2004; Emmanuel and Berkowitz, 2006; Delescluse and Chamot-Rooke, 2008; Iyer et al., 2010]. It was established for synthetic forsterite with grain sizes of 58-79 $\mu \mathrm{m}$. The results of Martin and Fyfe [1970] were confirmed by the data collected on synthetic forsterite by Wegner and Ernst [1983]. The dependency of the serpentinization rate with temperature (i.e., asymmetric bell shape with a maximum serpentinization temperature of $\sim 300^{\circ} \mathrm{C}$ ) found by Wegner and Ernst [1983] is confirmed in our study. However, our results differ slightly from the symmetric bell curve with a peak temperature of $260^{\circ} \mathrm{C}$ observed by Martin and Fyfe [1970].

[32] The time period needed to reach $\sim 70 \%$ of serpentinization is of $8 \mathrm{~d}$ at the peak temperature in the work of Martin and Fyfe [1970]. For an equivalent grain size and at the peak temperature $\left(300^{\circ} \mathrm{C}\right.$, run 2$), 70 \%$ of serpentinization is only reached after $470 \mathrm{~d}$ in the present study. Consequently, the rate of serpentinization found here is approximately 60 times slower than that reported by Martin and Fyfe [1970] (Figure 7). These authors did point out a discrepancy between the kinetics that they derived for runs with synthetic forsterite and the kinetics that they obtained for natural olivine with similar initial grain sizes, which were 2 to 3 times slower. A possible reason for this difference is the use of synthetic olivine [Martin and Fyfe, 1970] instead of natural San Carlos olivine, whose grain size was controlled more precisely. On the other hand, the present study shows that olivine alteration is no longer a simple function of IGS for sizes below $5 \mu \mathrm{m}$. Differences in olivine composition and, in particular, the absence or presence of a $\mathrm{FeO}$ component is another possible source for this discrepancy (e.g., which in turn may be related to the production, or not, of magnetite).

[33] Moreover, the high rates of serpentinization reported by Martin and Fyfe [1970], Wegner and Ernst [1983], and in this study for IGS below $5 \mu \mathrm{m}$, are associated with the production of chrysotile whereas lizardite is the main polymorph produced at mid-ocean ridges [Caruso and Chernosky, 1979; Wicks and Plant, 1979; Andreani et al., 2007]. Therefore, in addition to the problem associated with the size dependency of such high kinetic data (see above), their extrapolation to the serpentinization of olivine in oceanic peridotites may be questionable.

\subsection{From Experiments to Nature}

[34] Since the rate of olivine dissolution is directly related to its reactive surface area, the sigmoidal shape of the kinetic law derived in this study suggests that reactive surface area is created in the course of olivine serpentinization. This is consistent with residual olivine textures with etch pits and cracks, two features which promote the creation of new reactive surface area [MacDonald and Fyfe, 1985; Lüttge, 2005; Fletcher et al., 2006; Røyne et al., 2008; Kelemen and Matter, 2008; Iyer et al., 2008; Rudge et al., 2010; Okamoto et al., 2011].

[35] Velbel and Ranck [2008] and Velbel [2009] described the formation of etch pits on olivine surfaces during low-temperature weathering and argued that etch pits do not form in the course of oceanic serpentinization, which is a higher temperature process [Velbel, 2009]. Abundant etch pits with different morphology and sizes were however clearly observed in the present study and during alteration of olivine in the work of King et al. [2010] (and also probably in the work of Moody [1976, Figure 4] even if they were interpreted differently). As shown here, olivine grains in samples of the Southwest Indian Ridge (Figure 6) also exhibit mammilated surfaces. Etch pits in experimental and natural samples have comparable sizes of $1-10 \mu \mathrm{m}$. Etch pit-like indentations on olivine grains are also found in orogenic peridotite samples serpentinized during the exhumation of the Sulu ultrahighpressure metamorphic belt [Liu et al., 2010, Figure 2b]. This suggests that etch pit formation during serpentinization is a common feature. The similarity between reaction textures of olivine in natural samples and in our reaction products further suggests that the surface-dependant kinetics determined experimentally for initial olivine grain sizes $>5 \mu \mathrm{m}$ can be applied to natural serpentinization. However, this implies recognition of some critical differences that may influence the results, in particular petrological properties 

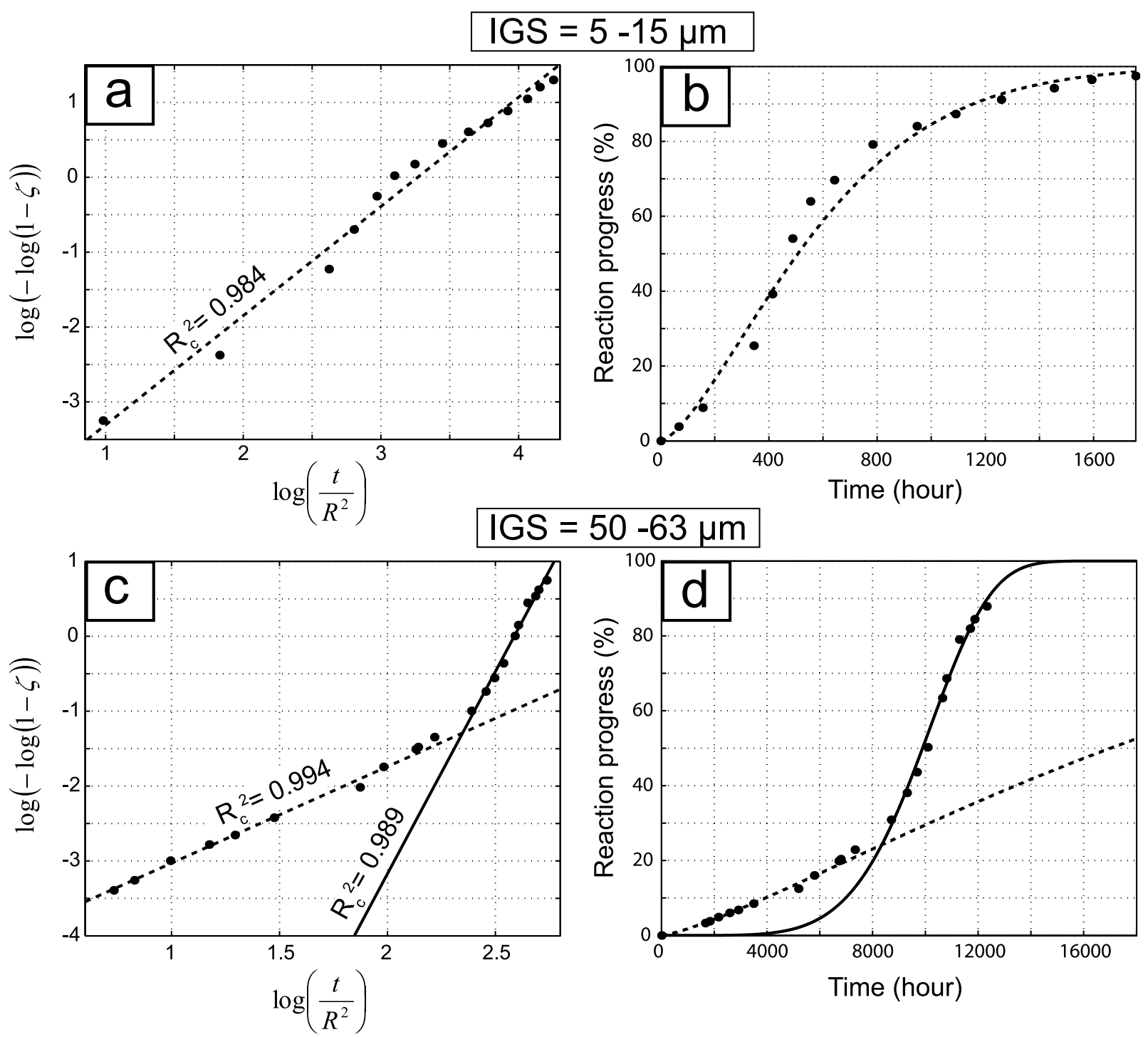

Figure A2. Reaction progress fitting (solid circles) for runs 22 (Figures A2a and A2b, IGS $=5-15 \mu \mathrm{m}$ ) and 2 (Figures A2c and A2d, IGS = 50-63 $\mu \mathrm{m}$ ) with Avrami-type functions (dashed line, olivine dissolution as dominant process; solid line, olivine dissolution enhanced by grain fracturing; see text). (a and c) Log-log plots with linear fits and linear correlation coefficients $\left(\mathrm{R}_{\mathrm{c}}^{2}\right)$. These fits give values of $k=$ 0.008514 and $n=1.459$ for Figure A2a, of $k=0.01333$ and $n=1.289$ for Figure A2c (dashed line), and of $k=8.561 \cdot 10^{-7}$ and $n=5.400$ for Figure A2c (solid line). (b and d) Corresponding data and Avrami plots for the reaction progress versus time curves.

such as the variability and evolution of the iron content in hydrous minerals and of the mineralogy in the abyssal peridotites, which suggest changing thermochemical conditions during natural serpentinization. The present experimental data set reproduces fundamental natural characteristics such as olivine dissolution features and lizardite crystallization, as well as it accounts for the effects of temperature and grain size. We suggest that future research addresses the dependency of the reaction kinetics with the solution composition (e.g., $\mathrm{pH}$, silica activity, redox) and water activity [e.g., Gasc et al., 2011]. The effect of pressure on serpentinization reaction kinetics is expected to be small compared to that of temperature, at least in the pressure range of oceanic hydrothermal alteration. However, the present results may not apply to serpentinization at the high pressures associated with subduction zones where antigorite is expected to form in lieu of lizardite, anyway.

\section{Appendix A}

\section{A1. Rate Law Function for the Serpentinization of San Carlos Olivine: Mathematical Expression}

[36] The entire set of raw experimental data including the mass of magnetite produced and reaction progress are given in the auxiliary material (Data Set S1). ${ }^{1}$ Corrected reaction progress data are also given therein; the corrections include

\footnotetext{
${ }^{1}$ Auxiliary materials are available at ftp://ttp.agu.org/apend/jb/ $2011 \mathrm{jb} 008842$.
} 
(1) the removal of the first reaction stage $(O)$, interpreted as an experimental artifact, and (2) the scaling of our data to maximum reaction progress of $100 \%$ instead of $\sim 90 \%$, that is, the maximum reaction progress due to olivine armored by brucite.

\section{A1.1. Effect of Temperature on the Serpentinization Reaction Kinetics}

[37] Using runs 7, 8, 10,11 and 12 (initial grain size, IGS = $38-50 \mu \mathrm{m})$, the effect of temperature ( $\mathrm{T}$ in $\mathrm{K})$ on reaction kinetics has been successfully fitted to a function (Figure A1) derived from Transition State Theory as proposed by Lasaga [1981] and Lasaga [1995]:

$f_{1}(T)=A \cdot \exp \left(-\frac{b}{T}\right) \cdot\left(1-\exp \left(-c \cdot\left(\frac{1}{T}-\frac{1}{T_{0}}\right)\right)\right)$ for $T \in\left[513 ; T_{0}\right]$

The fitted parameters are $A=808.3, b=3640 \mathrm{~K}, \mathrm{~T}_{0}=$ $623.6 \mathrm{~K}$ and $c=8759 \mathrm{~K}$.

[38] $f_{1}(\mathrm{~T})$ is an asymmetric bell-shaped function which therefore differs from the Gaussian function, $f_{2}(T)=\exp$ $\left(-\alpha\left(T-T_{m}\right)^{2}\right)$, which was also proposed to fit the data of Martin and Fyfe [1970] by Kelemen and Matter [2008]. We, however, fitted our data to a Gaussian function (Figure A1) for comparison, $\alpha=4.283 .10^{-4} \mathrm{~K}^{-2}$ and $T_{m}=555.5 \mathrm{~K}$.

\section{A1.2. Reaction Progress Expression}

[39] Reaction progresses $(\zeta)$ which display a sigmoidally shaped function with time ( $t$ in hour) are often treated with the Avrami formalism. The plot of the data in a $\log \left(\frac{t}{R^{2}}\right)$ (with $R=\mathrm{IGS} / 2$ in $\mu \mathrm{m})$ versus $\log (-\log (1-\zeta))$ diagram shows, however, that the Avrami formalism does not apply to all IGS (Figures A2a and A2c). For IGS of 50-63 $\mu \mathrm{m}$, the sum of two Avrami-type functions would be required. This is consistent with the notion that, at a minimum, two reaction processes operate for the largest olivine IGS, that is, grain fracturing and dissolution (see section 3.6).

[40] The reaction progress versus time function was thus fitted to a mathematical function inspired by the Avrami formalism [Avrami, 1939] with parameters depending on the IGS (Figure A2b for $5 \mu \mathrm{m}<\mathrm{IGS}<50 \mu \mathrm{m}$ and Figure A2d for IGS $50 \mu \mathrm{m}$ ). Within each range of IGS, extrapolation to other IGS is achieved with a simple geometrical surface term $\left(R^{2}\right.$, square radius). Overall, the reaction progress is expressed as follows:

$$
\zeta(t, T, R)=1-\exp \left(-k \cdot f_{1}(T) \cdot\left(\frac{t}{R^{2}}\right)^{n}\right),
$$

with $k$ and $n$ as Avrami parameters that depend on the IGS (see Figure A2).

[41] It should be noted that the corresponding kinetic function does not apply to runs 5, 6 and 24 with an IGS $<5 \mu \mathrm{m}$, for which the serpentinization processes are different (see main text for discussion).

[42] Acknowledgments. This research was funded by INSU-CNRS through the "Hydrogène Naturel" program. We acknowledge the thoughtful reviews by Peter Kelemen, Frieder Klein, and an anonymous reviewer. We are grateful to Roland Hellmann for correcting the English of this manuscript. We thank Nathaniel Findling, ISTerre, for his help with the FE-SEM. Abdeltif Lahfid and Emeline Charon, ENS, are acknowledged for their help with micro-Raman spectroscopy.

\section{References}

Allen, D. E., and W. E. Seyfried Jr. (2004), Serpentinization and heat generation: Constraints from Lost City and Rainbow hydrothermal systems, Geochim. Cosmochim. Acta, 68, 1347-1354, doi:10.1016/j. gca.2003.09.003.

Andreani, M., A. Baronnet, A. M. Boullier, and J. P. Gratier (2004), A microstructural study of a "crack-seal" type serpentine vein using SEM and TEM techniques, Eur. J. Mineral., 16, 585-595, doi:10.1127/09351221/2004/0016-0585.

Andreani, M., C. Mével, A.-M. Boullier and J. Escartin (2007), Dynamic control on serpentine crystallization in veins: Constraints on hydration processes in oceanic peridotites, Geochem. Geophys. Geosyst., 8, Q02012, doi:10.1029/2006GC001373.

Auzende, A. L., I. Daniel, B. Reynard, C. Lemaire, and F. Guyot (2004), High-pressure behaviour of serpentine minerals: A Raman spectroscopic study, Phys. Chem. Miner., 31, 269-277, doi:10.1007/s00269-004-0384-0.

Avrami, M. (1939), Kinetics of phase change. I General theory, J. Chem. Phys., 7, 1103-1112, doi:10.1063/1.1750380.

Bach, W., H. Paulick, C. J. Garrido, B. Ildefonse, W. P. Meurer and S. E. Humphris (2006), Unraveling the sequence of serpentinization reactions: Petrography, mineral chemistry, and petrophysics of serpentinites from MAR $15^{\circ} \mathrm{N}$ (ODP Leg 209, Site 1274), Geophys. Res. Lett., 33, L13306, doi:10.1029/2006GL025681.

Beard, J. S., B. R. Frost, P. Fryer, A. McCaig, R. Searle, B. Ildefonse, P. Zinin, and S. K. Sharma (2009), Onset and progression of serpentinization and magnetite formation in olivine-rich troctolite from IODP hole U1309D, J. Petrol., 50, 387-403, doi:10.1093/petrology/egp004.

Blum, A., and A. Lasaga (1988), Role of surface speciation in the lowtemperature dissolution of minerals, Nature, 331, 431-433, doi:10.1038/ $331431 \mathrm{a} 0$.

Boudier, F., A. Baronnet, and D. Mainprice (2010), Serpentine mineral replacements of natural olivine and their seismic implications: Oceanic lizardite versus subduction-related antigorite, J. Petrol., 51, 495-512, doi:10.1093/petrology/egp049.

Brantley, S. L., and N. P. Mellott (2000), Surface area and porosity of primary silicate minerals, Am. Mineral., 85, 1767-1783.

Cannat, M., D. Sauter, V. Mendel, E. Ruellan, K. Okino, J. Escartin, V. Combier, and M. Baala (2006), Modes of seafloor generation at a melt-poor ultraslow-spreading ridge, Geology, 34, 605-608, doi:10.1130/G22486.1.

Caruso, L. J., and J. V. Chernosky (1979), The stability of lizardite, Can. Mineral., 17, 757-769.

Chen, Y., and S. L. Brantley (2000), Dissolution of forsteritic olivine at $65^{\circ} \mathrm{C}$ and $2<\mathrm{pH}<5$, Chem. Geol., 165, 267-281, doi:10.1016/S00092541(99)00177-1

Delescluse, M., and N. Chamot-Rooke (2008), Serpentinization pulse in the actively deforming Central Indian Basin, Earth Planet. Sci. Lett., 276, 140-151, doi:10.1016/j.epsl.2008.09.017.

DeMets, C., R. G. Gordon, D. F. Argus, and S. Stein (1994), Effect of recent revisions to the geomagnetic reversal time scale on estimates of current plate motions, Geophys. Res. Lett., 21, 2191-2194, doi:10.1029/ 94GL02118.

Dick, H. J. B., J. Lin, and H. Schouten (2003), An ultraslow-spreading class of ocean ridge, Nature, 426, 405-412, doi:10.1038/nature02128.

Dilek, Y., A. J. Coulton, and S. D. Hurst (1997), Serpentinization and hydrothermal veining in peridotites at site 920 in the Mark area, Proc. Ocean Drill. Program Sci. Results, 153, 35-59.

Dyment, J., and J. Arkani-Hamed (1995), Spreading-rate-dependent magnetization of the oceanic lithosphere inferred from the anomalous skewness of marine magnetic anomalies, Geophys. J. Int., 121, 789-804, doi:10.1111/j.1365-246X.1995.tb06439.x.

Emmanuel, S., and B. Berkowitz (2006), Suppression and stimulation of seafloor hydrothermal convection by exothermic mineral hydration, Earth Planet. Sci. Lett., 243, 657-668, doi:10.1016/j.epsl.2006.01.028.

Escartín, J., G. Hirth, and B. Evans (1997), Effects of serpentinization on the lithospheric strength and the style of normal faulting at slow-spreading ridges, Earth Planet. Sci. Lett., 151, 181-189, doi:10.1016/S0012821X(97)81847-X.

Fletcher, R. C., H. L. Buss, and S. L. Brantley (2006), A spheroidal weathering model coupling porewater chemistry to soil thickness during steady-state denudation, Earth Planet. Sci. Lett., 244, 444-457, doi:10.1016/j.epsl.2006.01.055.

Frost, B. R., and J. S. Beard (2007), On silica activity and serpentinization, J. Petrol., 48, 1351-1368, doi:10.1093/petrology/egm021.

Fyfe, W. S. (1974), Heats of chemical reactions and submarine heat production, Geophys. J. Int., 37, 213-215, doi:10.1111/j.1365-246X.1974. tb02454.x.

Gasc, J., F. Brunet, N. Bagdassarov, and V. Morales-Flórez (2011), Electrical conductivity of polycrystalline $\mathrm{Mg}(\mathrm{OH})_{2}$ at $2 \mathrm{GPa}$ : Effect of grain 
boundary hydration-dehydration, Phys. Chem. Miner., 38, 543-556, doi:10.1007/s00269-011-0426-3.

Grauby, O., A. Baronnet, B. Devouard, K. Schoumacker, and L. Demirdjian (1998), The chrysotile-polygonal serpentine-lizardite suite synthesized from a $3 \mathrm{MgO}-2 \mathrm{SiO}_{2}$-excess $\mathrm{H}_{2} \mathrm{O}$ gel, Terra Nova, 10, suppl., 24.

Gravenor, L. P., and R. K. Leavitt (1981), Experimental formation and significance of etch patterns on detrital garnets, Can. J. Earth Sci., 18, 765-775, doi:10.1139/e81-070.

Hänchen, M., V. Prigiobbe, G. Storti, T. M. Seward, and M. Mazotti (2006), Dissolution kinetics of fosteritic olivine at $90-150^{\circ} \mathrm{C}$ including effects of the presence of $\mathrm{CO}_{2}$, Geochim. Cosmochim. Acta, 70 , 4403-4416, doi:10.1016/j.gca.2006.06.1560.

Iyer, K., B. Jamtveit, J. Mathiesen, A. Malthe-Sørenssen, and J. Feder (2008), Reaction-assisted hierarchical fracturing during serpentinization, Earth Planet. Sci. Lett., 267, 503-516, doi:10.1016/j.eps1.2007.11.060.

Iyer, K., L. H. Rüpke, and J. P. Morgan (2010), Feedbacks between mantle hydration and hydrothermal convection at ocean spreading centers, Earth Planet. Sci. Lett., 296, 34-44, doi:10.1016/j.eps1.2010.04.037.

Kelemen, P. B., and J. Matter (2008), In situ carbonation of peridotite for $\mathrm{CO}_{2}$ storage, Proc. Natl. Acad. Sci. U. S. A., 105, 17,295-17,300 doi:10.1073/pnas.0805794105.

King, H. E., O. Plümper, and A. Putnis (2010), Effect of secondary phase formation on the carbonation of olivine, Environ. Sci. Technol., 44, 6503-6509, doi:10.1021/es9038193.

Klein, F., W. Bach, N. Jöns, T. McCollom, B. Moskowitz, and T. Berquó (2009), Iron partitioning and hydrogen generation during serpentinization of abyssal peridotites from $15^{\circ} \mathrm{N}$ on the Mid-Atlantic Ridge, Geochim. Cosmochim. Acta, 73, 6868-6893, doi:10.1016/j.gca.2009.08.021.

Kretz, R. (1983), Symbols for rock-forming minerals, Am. Mineral., 68 , $277-279$.

Lasaga, A. C. (1981), Transition state theory, in Kinetics of Geochemical Processes, edited by A. C. Lasaga and R. J. Kirkpatrick, pp. 135-169, Mineral. Soc. of Am., Washington, D. C.

Lasaga, A. C. (1995), Fundamental approaches in describing mineral dissolution and precipitation rates, in Chemical Weathering Rates of Silicate Minerals, edited by A. F. White and S. L. Brantley, pp. 23-86, Mineral. Soc. of Am., Washington, D. C.

Lemaire, C., F. Guyot, and B. Reynard (1999), Vibrational spectroscopy (IR and Raman) of $\mathrm{OH}$ groups in chrysotile lizardite and antigorite, paper presented at European Union of Geosciences 10, Strasbourg, France.

Liu, Q., Q. Zeng, J. Zheng, T. Yang, N. Qiu, Z. Liu, Y. Luo, and Z. Jin (2010), Magnetic properties of serpentinized garnet peridotites from the CCSD main hole in the Sulu ultrahigh-pressure metamorphic belt, eastern China, J. Geophys. Res., 115, B06104, doi:10.1029/2009JB000814.

Lüttge, A. (2005), Etch pit coalescence, surface area, and overall mineral dissolution rates, Am. Mineral., 90, 1776-1783, doi:10.2138/am.2005. 1734.

Macdonald, A. H., and W. S. Fyfe (1985), Rate of serpentinization in seafloor environments, Tectonophysics, 116, 123-135, doi:10.1016/ 0040-1951(85)90225-2.

Malvoisin, B., J. Carlut, and F. Brunet (2012) Serpentinization of oceanic peridotites: 1. A high-sensitivity method to monitor magnetite production in hydrothermal experiments, J. Geophys. Res., 117, B01104, doi:10.1029/2011JB008612

Marcaillou, C. (2011), Serpentinisation et production d'hydrogène en contexte de dorsale lente: Approche expérimentale et numérique, Ph.D thesis, 296 pp., Univ. of Grenoble, Grenoble, France, 21 January.

Marcaillou, C., M. Muñoz, O. Vidal, T. Parra, and M. Harfouche (2011), Mineralogical evidence for $\mathrm{H}_{2}$ degassing during serpentinization at $300^{\circ} \mathrm{C} / 300$ bar, Earth Planet. Sci. Lett., 303, 281-290, doi:10.1016/j. eps1.2011.01.006.

Martin, B., and W. S. Fyfe (1970), Some experimental and theoretica observations on the kinetics of hydration reactions with particular reference to serpentinization, Chem. Geol., 6, 185-202, doi:10.1016/00092541(70)90018-5.

Mével, C., et al. (1997), Sampling the South West Indian Ridge: First results of the EDUL cruise (R/V Marion Dufresne II, August 1997), InterRidge News, 6, 25-26.
Moody, J. B. (1976), An experimental study on the serpentinization of ironbearing olivines, Can. Mineral., 14, 462-478.

Normand, C., A. E. Williams-Jones, R. F. Martin, and H. Vali (2002), Hydrothermal alteration of olivine in a flow-through autoclave: Nucleation and growth of serpentine phases, Am. Mineral., 87, 1699-1709.

Oelkers, E. H. (2001), An experimental study of forsterite dissolution as a function of temperature, and aqueous $\mathrm{Mg}$ and $\mathrm{Si}$ concentration, Chem. Geol., 175, 485-494, doi:10.1016/S0009-2541(00)00352-1.

Okamoto, A., Y. Ogasawara, Y. Ogawa, and N. Tsuchiya (2011), Progress of hydration reactions in olivine- $\mathrm{H}_{2} \mathrm{O}$ and orthopyroxenite- $\mathrm{H}_{2} \mathrm{O}$ systems at $250^{\circ} \mathrm{C}$ and vapor-saturated pressure, Chem. Geol., 289, 245-255, doi:10.1016/j.chemgeo.2011.08.007.

Oufi, O., M. Cannat, and H. Horen (2002), Magnetic properties of variably serpentinized abyssal peridotites, J. Geophys. Res., 107(B5), 2095, doi:10.1029/2001JB000549.

Pokrovsky, O. S., and J. Schott (2000), Kinetics and mechanism of forsterite dissolution at $25^{\circ} \mathrm{C}$ and $\mathrm{pH}$ from 1 to 12 , Geochim. Cosmochim. Acta, 64, 3313-3325, doi:10.1016/S0016-7037(00)00434-8.

Rosso, J. J., and D. J. Rimstidt (2000), A high resolution study of forsterite dissolution rates, Geochim. Cosmochim. Acta, 64, 797-811, doi:10.1016/ S0016-7037(99)00354-3.

Røyne, A., B. Jamtveit, J. Mathiesen, and A. Malthe-Sørenssen (2008), Controls on rock weathering rates by reaction-induced hierarchical fracturing, Earth Planet. Sci. Lett., 275, 364-369, doi:10.1016/j. eps1.2008.08.035.

Rudge, J. F., P. B. Kelemen, and M. Spiegelman (2010), A simple model of reaction-induced cracking applied to serpentinization and carbonation of peridotite, Earth Planet. Sci. Lett., 291, 215-227, doi:10.1016/j. epsi.2010.01.016.

Rumori, C., M. Mellini, and C. Viti (2004), Oriented, non-topotactic olivine $\rightarrow$ serpentine replacement in mesh-textured, serpentinized peridotites, Eur. J. Mineral., 16, 731-741, doi:10.1127/0935-1221/2004/0016-0731.

Seyfried, W. E., Jr., D. I. Foustoukos, and Q. Fu (2007), Redox evolution and mass transfer during serpentinization: An experimental and theoretical study at $200^{\circ} \mathrm{C}, 500$ bar with implications for ultramafic-hosted hydrothermal systems at Mid-Ocean Ridges, Geochim. Cosmochim. Acta 71,3872-3886, doi:10.1016/j.gca.2007.05.015.

van der Lee, J., and L. De Windt (2002), CHESS tutorial and cookbook: Updated for version 3.0., Rep. $L H M / R D / 02 / 13,116$ pp., Ecole Natl. Supér. des Mines de Paris, Paris

Velbel, M. (2009), Dissolution of olivine during natural weathering, Geochim. Cosmochim. Acta, 73, 6098-6113, doi:10.1016/j.gca.2009.07.024.

Velbel, M. A., and J. M. Ranck (2008), Etch pits on naturally altered olivine from dunites of the Appalachian Blue Ridge Mountains, North Carolina, USA, Mineral. Mag., 72, 145-148, doi:10.1180/minmag.2008.072.1.145. Wegner, W. W., and W. G. Ernst (1983), Experimentally determined hydration and dehydration reaction rates in the system $\mathrm{MgO}-\mathrm{SiO}_{2}-\mathrm{H}_{2} \mathrm{O}, \mathrm{Am}$. J. Sci., 283-A, 151-180.

Wicks, F. J., and A. G. Plant (1979), Electron microprobe and X-ray microbeam studies of serpentine minerals, Can. Mineral., 17, 785-830.

Wicks, F. J., and E. J. W. Whittaker (1977), Serpentine texture and serpentinization, Can. Mineral., 15, 459-488.

Wogelius, R. A., and J. V. Walther (1992), Olivine dissolution kinetics at near-surface conditions, Chem. Geol., 97, 101-112, doi:10.1016/00092541(92)90138-U.

F. Brunet and J. Carlut, Laboratoire de Géologie, Ecole Normale Supérieure, CNRS, 24 rue Lhomond, F-75231 Paris, France.

M. Cannat and S. Rouméjon, Laboratoire de Géosciences Marines, CNRS, Institut de Physique du Globe de Paris, 1 rue Jussieu, F-75238 Paris, France.

B. Malvoisin, Maison des Géosciences, Institut des Sciences de la Terre, Université Grenoble 1, CNRS, BP 53, F-38041 Grenoble, France. (benjamin.malvoisin@ujf-grenoble.fr) 